\title{
Effect of contrasting water supply on the diameter growth of Norway spruce and aspen in mixed stands: a case study from the southern Russian taiga
}

\author{
Fyodor TATARINOVa,b,c*, Yury BOCHKAREV ${ }^{\mathrm{d}}$, Alexander OLTCHEV ${ }^{\mathrm{a}, \mathrm{e}}$, Nadezhda NADEZHDINA $^{\mathrm{b}}$, \\ Jan CERMAK ${ }^{\mathrm{b}}$ \\ ${ }^{a}$ Institute of Ecology and Evolution, Leninsky prospekt 33, Moscow, Russia \\ $\mathrm{b}$ Institute of Forest Ecology, Mendel University of Agriculture and Forestry, Brno, Czech Republic \\ c Present address: Institute of Forest Ecosystem Research (IFER), 1544 Jilove u Prahy, 254 01, Czech Republic \\ d Faculty of Geography, Lomonosov Moscow State University, Russia \\ e Institute of Bioclimatology, Georg-August University, Goettingen, Germany
}

(Received 21 June 2004; accepted 27 May 2005)

\begin{abstract}
Stem radial growth of Norway spruce (Picea abies (L.) Karst.), aspen (Populus tremula L.), birch (Betula alba L.), alder (Alnus incana (L.) Moench) and mountain ash (Sorbus aucuparia L.) was measured in an unmanaged mixed uneven-aged tree stand in the southern taiga of European Russia by band dendrometers during the growing seasons of 2000-2001. In addition woody cores were taken from sample spruce and aspen trees using increment borers for dendrochronological analysis. Analysis of the tree rings was made for period from 1999 to 2002, the period while daily meteorological data were available. Spruce and aspen represented 40 and $44 \%$ of the entire stand basal area, respectively. However, basal area has grown over 60\% of the total in spruce and less than $15 \%$ in aspen for each year during the period of 1999 2002. These results indicate the transformation processes of secondary aspen-spruce stands of the Southern European Taiga into a mixed spruceaspen-birch stands. The most intensive radial growth of the spruce trees was observed in 2000 with high over-watering conditions in summer, whereas the highest radial growth in aspen was observed during the extremely dry growing season of 2002. The basal area growth for entire forest stand ranged from $5.3 \mathrm{~m}^{2} \mathrm{ha}^{-1}$ in 1999 to $11.4 \mathrm{~m}^{2} \mathrm{ha}^{-1}$ in 2000 . Annual increments of radial growth measured by dendrometers and by microscopic evaluation of woody cores were quite similar in spruce. In contrast, this comparison was poor for aspen trees because zero growth in some of aspen trees (measured by dendrometers) was occurred.
\end{abstract}

stem radial growth / Central Russia / dendrochronological analysis / Norway spruce / unmanaged forest

Résumé - Effets d'une alimentation en eau variée sur la croissance en diamètre de l'épicéa et du tremble dans des peuplements mélangés étudiés dans le sud de la taïga russe. La croissance radiale saisonnière de l'épicéa (Picea abies (L.) Karst.), du tremble (Populus tremula L.), du bouleau (Betula alba L.), de l'aulne (Alnus incana (L.) Moench) et du sorbier (Sorbus aucuparia L.) a été mesurée, dans une forêt mixte non gérée dominée par l'épicéa et le tremble, et située dans la taïga du sud en Russie d'Europe. Les mesures ont été effectuées à l'aide de dendromètres à ruban pendant les saisons 2000-2001 en parallèle avec les données météorologiques. En plus des carottes de bois ont été prélevées sur tous les épicéas et trembles mesurés pour faire une analyse dendrochronologique. L'épicéa et le tremble représentaient 40 et $44 \%$ de la surface terrière du peuplement. Néanmoins, annuellement dans la période 1999-2002, la croissance de la surface terrière de l'épicéa représentait plus de $60 \%$ de la croissance totale de la surface terrière contre moins de $15 \%$ pour le tremble. Ces résultats révèlent la transformation de la forêt secondaire de trembles en forêt mixte à dominance d'épicéa. La croissance la plus forte de l'épicéa été observée pendant la saison 2000, caractérisée par une surabondance de l'eau dans le sol pendant l'été, tandis que la croissance maximale du tremble a été observée pendant la saison extrêmement sèche du 2002. La croissance totale de la surface terrière du peuplement variait de $5.3 \mathrm{~m}^{2}$ ha ${ }^{-1}$ en 1999 jusqu'à $11.4 \mathrm{~m}^{2} \mathrm{ha}^{-1}$ en 2000 . La croissance annuelle radiale mesurée par les dendromètres et par la mesure des accroissements annuels sur les carottes de sondage était similaire chez l'épicéa. En contraste chez le tremble, cette concordance était faible à cause de l'absence de croissance radiale d'une partie des trembles mesurés par les dendromètres.

Russie centrale / analyse dendrochronologique / épicéa / tremble / forêt non gérée

\section{INTRODUCTION}

Norway spruce (Picea abies (L.) Karst.) is one of the most important tree species for timber production in the entire zone of the Southern European taiga in Russia. It is usually dominated in the primary (non-managed) forest stands. Aspen (Populus tremula L.) is the dominant tree species of secondary forests (naturally regenerated after clear cutting, windthrow/

\footnotetext{
* Corresponding author: fedor.tatarinov@ifer.cz.
} 
break, etc.) especially on the loamy soils $[17,18]$. Since many forest stands in the region are practically unmanaged (in particular, in the case of clear-cut stands are often left for natural regeneration), mixed stand with dominant spruce and aspen trees in certain different proportions and with admixture of some other deciduous species are typical in the region of the southern European taiga.

The area of the southern European taiga is characterised by moderate humid climate. Annual precipitation usually exceeds the evapotranspiration [13]. Very high level of ground water due to surplus precipitation, peat or loamy soils with low infiltration rate, flat landscape and low surface runoff results in development of rather shallow root system in the different tree species growing in this area [8].

Long-term meteorological data records indicate that the recent global climatic changes resulted in significantly increase of the frequency of summer droughts in the Central Russia. According to the data of the meteorological station in the Central Forest Biosphere Natural Reserve (CFBR, 56 $30^{\circ} \mathrm{N}, 33^{\circ}$ $00^{\prime} \mathrm{E}$, Tver region, Russia), during the 10 -years period from 1992 to 2002 four strong summer droughts (in 1992, 1999, 2001 and 2002) were observed. This was indicated by precipitation totals from May to September for these years were below the confidence interval for long-term mean, whereas mean temperatures for the same period were within the corresponding confidence interval. According to climatological data the strong droughts in this area can be observed once per 5-7 years, only.

It can be expected that rapid decrease of ground water table during such droughts can result in a lack of available soil water in the tree root zone, root mortality and finally in significant decrease of root water uptake, transpiration and photosynthesis rates [13].

The different tree species respond differently to water stress conditions $[8,9,11,20-22]$. Spruce trees with shallow root systems may be more affected by short-term drought than aspens with deeper root systems. For spruce trees it is manifested through decrease of tree transpiration [14] and canopy gross primary production (GPP) [20, 22]. However, the possible response of different tree species to the climatic extremes is not sufficiently known yet. In particular, the important question is, what is the impact of climatic extremes on stem growth in spruce and aspen as dominant tree species in the region?

Unique anomalous weather conditions favourable for such studies occurred during the growing seasons 1999-2002: summers 1999 and especially 2002 were extremely dry, while 2000 was very wet (Tab. I). Growing season 2001 was close to mean climatic conditions.

The measurements of stand biometry and tree stem growth were carried out as a part of the complex research study in a small forested watershed in the basin of Upper Volga within the framework of international project "Volgaforest" [13].

The main goals of this paper are:

- to reveal the seasonal dynamics of radial growth of different tree species in a mixed unmanaged forest stand;

- to study, how the extreme moisture conditions (drought or water surplus) affected the growth of main tree species, namely spruce and aspen;
Table I. Meteorological characteristics of growing seasons 19992002 in Central Russia. Data from Central Forest Biospheric Reserve $\left(56^{\circ} 30^{\prime} \mathrm{N}, 33^{\circ} 00^{\prime} \mathrm{E}\right)$.

\begin{tabular}{lcc}
\hline Year & $\begin{array}{c}\text { Mean air temperature from } \\
\text { May to September }\end{array}$ & $\begin{array}{c}\text { Precipitation total from } \\
\text { May to September }\end{array}$ \\
\hline 1999 & 14.1 & 242 \\
2000 & 12.4 & 436 \\
2001 & 14.0 & 249 \\
2002 & 14.1 & 146 \\
Mean & 13.2 & 386 \\
$1970-2002$ & & 111 \\
Std. deviation & 1.0 & \\
1970-2002 & & \\
\hline
\end{tabular}

- to compare the stem radial growth as measured by dendrometers and evaluated from analysis of tree rings.

\section{MATERIALS AND METHODS}

\subsection{Site description}

Experimental plot (1.046 ha) was selected in unmanaged unevenaged mixed forest stand situated $5 \mathrm{~km}$ from the town Peno in the region of upper Volga $\left(56^{\circ} 58^{\prime} \mathrm{N}, 32^{\circ} 52^{\prime} \mathrm{E}\right)$. Forest consists mostly from Norway spruce (Picea abies (L.) Karst.) and aspen (Populus tremula L.), with admixture of birch (Betula alba L.), mountain ash (Sorbus aucuparia L.), alder (Alnus incana (L.) Moench) and some old Scots pine (Pinus sylvestris L.) Experimental plot is characterised by very rich herbaceous vegetation. About $70 \%$ of sample plot with $1-1.5 \mathrm{~m}$ deep underground water table on the brown sandy-loam soils was covered by mixed uneven-aged forest stand and rich herbaceous layer. A boggy area with underground water table rising up to $20 \mathrm{~cm}$ on the dark-brown clayish-loam soils, with nettle in herb layer and sparse tree vegetation consisting mainly from alder and aspen presented the rest of plot [14].

\subsection{Forest inventory and dendrometric measurements}

Forest inventory included the measurement of the tree diameters at breast height (DBH) and tree heights. The structure of the root system and the size of root boles (diameter and depth), as well as tree heights, were derived using the measurements of wind-fallen trees. Root boles were measured in 4 spruces, 3 aspens and 2 birches. The tree heights were measured in 18 spruces, 10 birches, 13 aspens, 5 alders and 1 mountain ash. The allometric relations between tree height and $\mathrm{DBH}$ were thus derived.

During the growing season of 2000 the radial growth of stems was measured in altogether 31 sample trees of 5 species: 13 Norway spruces (Picea abies (L.) Karst.), 11 aspens (Populus tremula L.), 3 birches (Betula alba L.), 2 mountain ashes (Sorbus aucuparia L.) and 2 alders (Alnus incana (L.) Moench) by stainless steel band dendrometers (EMS, Brno, Czech republic). All sample trees except one aspen and one alder trees were taken from the dryer part of sample plot. Observations were made from April to late October once per two weeks (Tab. II). Number of sample trees per species was chosen according to their portion in the stand basal area. Within each species the sample trees were selected according to its tree basal area distribution [4]. In addition, one observation was done in November 2001 (i.e. only the total seasonal growth for this year was obtained). 
Table II. Characteristics of the sample trees. Environment: 1, dense young alder - mountain ash cohort near the forest edge; 2, open boggy place; 3 , mixed relatively dry stand; 4 , forest edge; 5 , dense group of aspens; 6 , in a windfall near the border of boggy part.

\begin{tabular}{|c|c|c|c|c|}
\hline Species & $\begin{array}{l}\text { DBH } \\
(\mathrm{cm})\end{array}$ & $\begin{array}{c}\text { Crown } \\
\text { projected area } \\
\left(\mathrm{m}^{2}\right)\end{array}$ & $\begin{array}{c}\text { Dendrochronol. } \\
\text { series } \\
\text { (years) }\end{array}$ & Environment \\
\hline Alder & 14.8 & 22.8 & & 1 \\
\hline Mountain ash & 9.4 & 6.2 & & 1 \\
\hline Alder & 31.2 & & & 2 \\
\hline Aspen & 20.6 & & & 2 \\
\hline Aspen & 32.7 & 29.2 & 18 & 2 \\
\hline Aspen & 44.0 & 39.9 & 20 & 3 \\
\hline Aspen & 51.2 & 113.1 & 12 & 3 \\
\hline Birch & 27.0 & & & 3 \\
\hline Birch & 38.7 & 45.3 & & 3 \\
\hline Birch & 60.8 & & & 3 \\
\hline Mountain ash & 18.9 & & & 3 \\
\hline Spruce & 11.7 & 5.3 & $22^{*}$ & 3 \\
\hline Spruce & 16.7 & 5.7 & $53^{*}$ & 3 \\
\hline Spruce & 20.1 & & $62^{*}$ & 3 \\
\hline Spruce & 22.1 & & $69^{*}$ & 3 \\
\hline Spruce & 25.3 & & 52 & 3 \\
\hline Spruce & 29.8 & 20 & & 3 \\
\hline Spruce & 33.6 & & $97^{*}$ & 3 \\
\hline Spruce & 36.9 & 12.2 & 48 & 3 \\
\hline Spruce & 39.8 & & & 3 \\
\hline Spruce & 42.3 & 22.8 & 49 & 3 \\
\hline Spruce & 45.7 & & 43 & 3 \\
\hline Spruce & 60.4 & 64.3 & 77 & 3 \\
\hline Spruce & 66.2 & & 64 & 4 \\
\hline Aspen & 28.4 & 10.3 & 31 & 5 \\
\hline Aspen & 34.8 & & 20 & 5 \\
\hline Aspen & 37.2 & 15.5 & 16 & 5 \\
\hline Aspen & 42.3 & & 29 & 5 \\
\hline Aspen & 46.4 & & 17 & 5 \\
\hline Aspen & 46.6 & & 12 & 5 \\
\hline Aspen & 57.0 & & & 6 \\
\hline
\end{tabular}

* Trees with core up to the middle of trunk.

Subsequently the woody cores were taken by Suunto (Finland) increment borers from two opposite sides, northern and southern, of all sample spruce and aspen trees in October 2002 (except of two aspen trees which died earlier) in order to evaluate the stem growth over a longer period of time and compare two methods of radial growth measurements. Totally 40 cores from 11 spruce and 9 aspen trees were processed. Annual ring widths were measured by scanning of cores and further computer image analysis. Stand age was determined (1) by calculating annual rings of the stumps found at the experimental plot, and (2) by similar calculation on the tree rings on sample cores (for spruces only).

\subsection{Meteorology}

The whole set of main daily meteorological parameters (air temperature and humidity, global radiation, wind speed and precipitation) was measured at meteorological tower above a forest canopy during the whole growing season of 2000 (from May to October). Devices for measurements of the air temperature and humidity, wind speed and wind direction were produced by Thedor Friedrichs $\mathrm{GmbH}$ (Germany). For global solar radiation measurements the pyranometer CM 11 (Kipp \& Zonnen, The Netherlands) was used. Air temperature and global radiation were also measured at the experimental plot in 1999 from mid June to early October using the other measuring equipment (Schrenk, Austria) and stored to the datalogger EMS (Brno, Czech Republic).

The water table was measured at the holes bored in four contrasting points within the experimental plot from middle of June to early November 1999 and from late May to mid September 2000. One point was selected an existing well (about $30 \mathrm{~m}$ from plot), two others were bored in the boggy part of the forest (at the same elevation as previous and at place which was $0.4 \mathrm{~m}$ higher), and the last hole was bored at the highest point of the plot $0.9 \mathrm{~m}$ above the well level. The depth of the last hole was $140 \mathrm{~cm}$; other holes reached the depth of $120 \mathrm{~cm}$. Measurements were performed with different time intervals from one day to two weeks by tape measure (precision $\pm 10 \mathrm{~mm}$ ).

\subsection{Data processing}

The following variables describing stem growth were calculated: increment of stem circumference since the start of measurements in the considered season $(\mathrm{d} C)$; corresponding radius increment $\mathrm{d} r=$ $\mathrm{d} C /(2 \pi)$; radial growth rate $\mathrm{d} r / \mathrm{d} t=\left[\mathrm{d} r\left(t_{2}\right)-\mathrm{d} r\left(t_{1}\right)\right] /\left(t_{2}-t_{1}\right)$; basal area growth $\mathrm{d} S=\pi\left[(D B H / 2+\mathrm{d} r)^{2}-D B H^{2} / 4\right]$; relative basal area growth $\mathrm{d} S_{r}=\mathrm{d} S /\left(\pi \cdot D B H^{2} / 4\right)$. Growth of stand basal area from the beginning of growing season was estimated in a similar manner as is generally used in forestry $[2,3]$ :

(1) The equations relating tree basal area growth (since the beginning of growing season) to tree DBH were derived separately for each species under study and each particular day of measurement by means of regression. Multiplicative model $\left(y=a \cdot x^{b}\right)$ was applied for spruce and aspen and linear model $(y=a+b \cdot x)$ was applied for other species. Measured dendrometric data in sample trees were used for this purpose.

(2) The obtained regression equations were applied to calculate the basal area growth of mean trees for each 2-cm-DBH class. The growth of stand basal area for each day of measurements was estimated by two steps: multiplication of the mean basal area changes for each class by corresponding numbers of trees for each period and summarising afterwards. The equation for the basal area growth can be written as:

$$
S(t)-S\left(t_{0}\right)=\sum_{i=1}^{k} \sum_{j=1}^{m} f_{t, i}(2 \cdot(j-1)+1) \cdot n_{i j},
$$

where $t$ and $t_{0}$ are the current day and the day of the first measurement in the growing season, $S(t)$ is the stand basal area (in $\mathrm{m}^{2} \mathrm{ha}^{-1}$ ), $k$ and $m$ are numbers of species and DBH classes, $n_{i j}$ is the stocking density of species $i$ in the DBH class $j$, and $f_{t, i}(2 \cdot(j-1)+1)$ is the regression equation between tree basal area growth and tree DBH for moment $t$ and species $i$. The similar scaling procedure was applied to the annual growth data for 1999-2002 obtained from analysis of the tree rings.

The daily evapotranspiration $\left(E_{T}\right)$ was estimated using the model "MixFor-SVAT" [12]. The model describes the following processes: radiation transport within a mixed forest stand, turbulent exchange of sensible heat, water vapour and $\mathrm{CO}_{2}$ between soil, forest canopy and the atmosphere, interception of precipitation by forest overstorey and understorey, transpiration and water uptake by trees and understorey plants, water infiltration in the soil, soil heat exchange, photosynthesis and respiration of overstorey and understorey vegetation. The model 


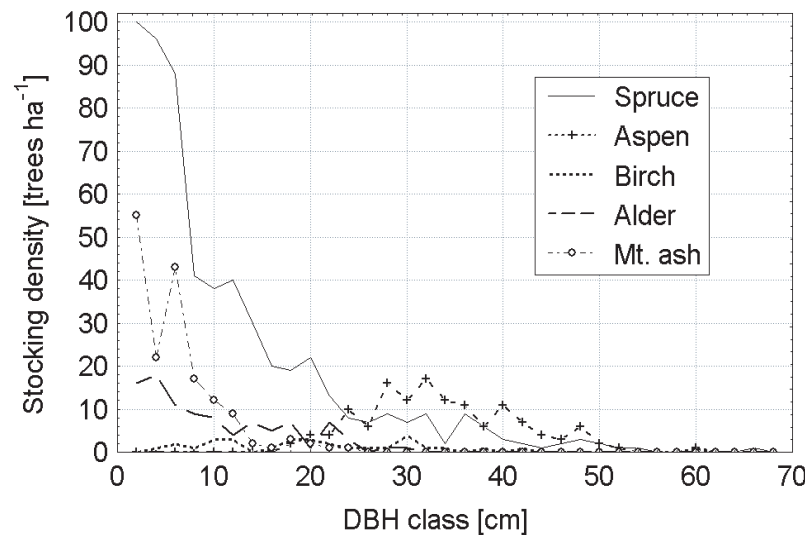

Figure 1. Tree diameter distribution at the experimental stand in Peno.

uses the air temperature and humidity, wind speed, precipitation and global radiation as input meteorological parameters. In our study the daily meteorological data for all period of dendrological observation were estimated using special model (SVAT-regio) of spatial interpolation of the meteorological information. For spatial data interpolation the model uses the modified method of universal kriging [10, 15]. For interpolation procedure the meteorological data from two meteorological stations (CFBR in $55 \mathrm{~km}$ to the south from our experimental plot and Ostashkov in $20 \mathrm{~km}$ to the east), digital maps of relief and landuse were used. Simulated daily evaporation values were used to calculate the rainfall deficit (WD) as the cumulative difference between daily precipitation amounts and $E_{T}[6]$.

\section{RESULTS}

\subsection{Stand tree distribution and biometry}

Diameter distribution of the spruces was typical for an unmanaged stand: all diameter classes were presented and stocking density decreased exponentially with increasing $\mathrm{DBH}$ class (Fig. 1). Aspen, another dominant tree species, prevailed in higher diameter classes (in the range from 25 to $50 \mathrm{~cm}$ ). No aspen trees with diameter smaller $20 \mathrm{~cm}$ were observed. Such diameter distribution of the dominant tree species indicates possible changes in succession from the secondary aspen stand to the mixed spruce stand, which at present is very typical in the region. Admixture of birches was presented in all diameter classes, alder and mountain ash prevailed (together with spruce) in the understorey.

Age of aspen trees ranged between 55 to 75 years old; spruce was presented in all age classes up to 100 years old. Aspen represented substantial fraction of entire stand in basal area, but not in stocking density, due to relatively low number of large trees (Fig. 2).

The dependence of tree height on DBH showed that spruce trees were generally lower than deciduous trees of the same diameter (Fig. 3). No any dependence of the DBH on the height was observed for aspen trees with DBH larger than $30 \mathrm{~cm}$.

\subsection{Weather conditions during seasons 1999-2002}

The growing season 2000 was characterised by very wet summer. The growing seasons 1999 and 2001-2002 were very
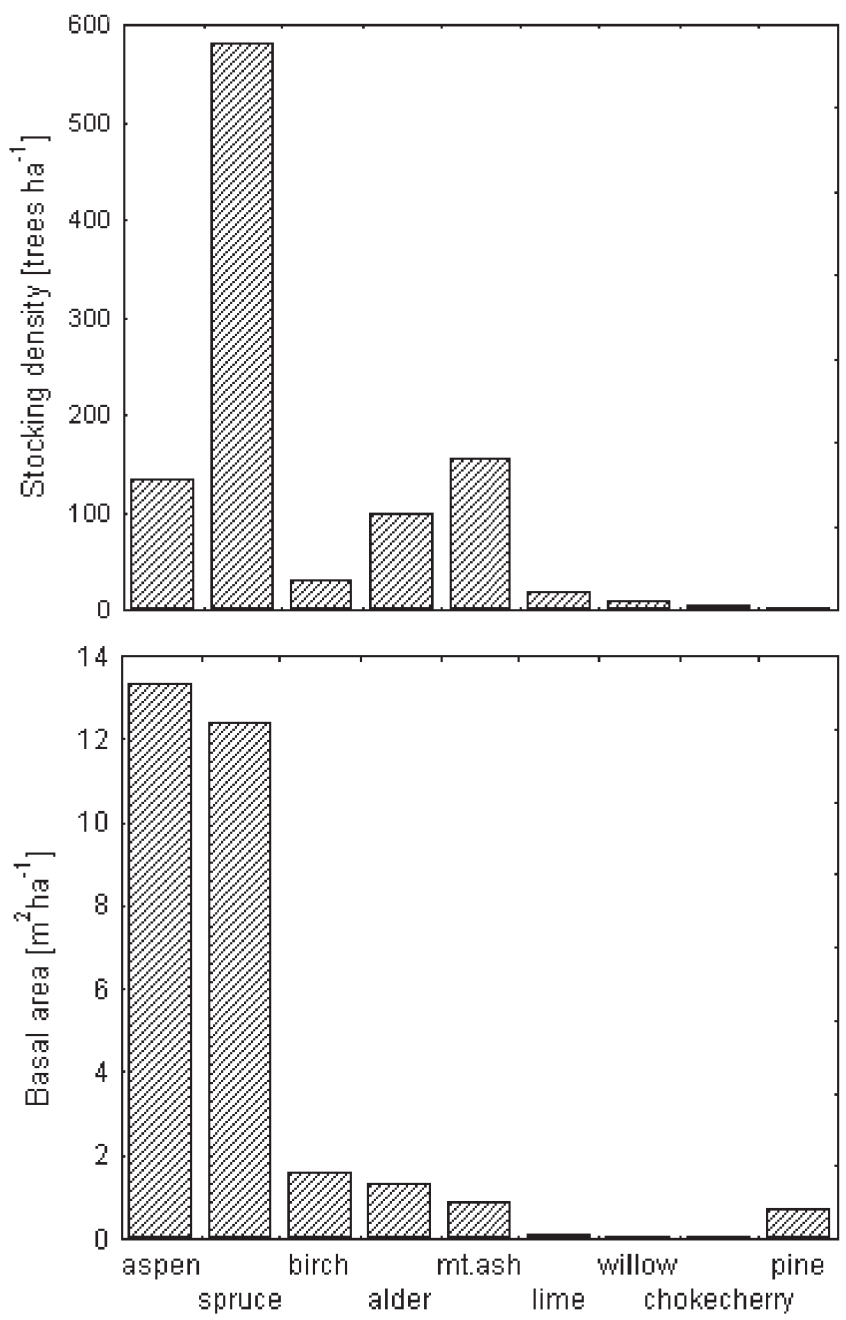

Figure 2. Stocking density (a) and basal area (b) in the individual species at the experimental stand in Peno.

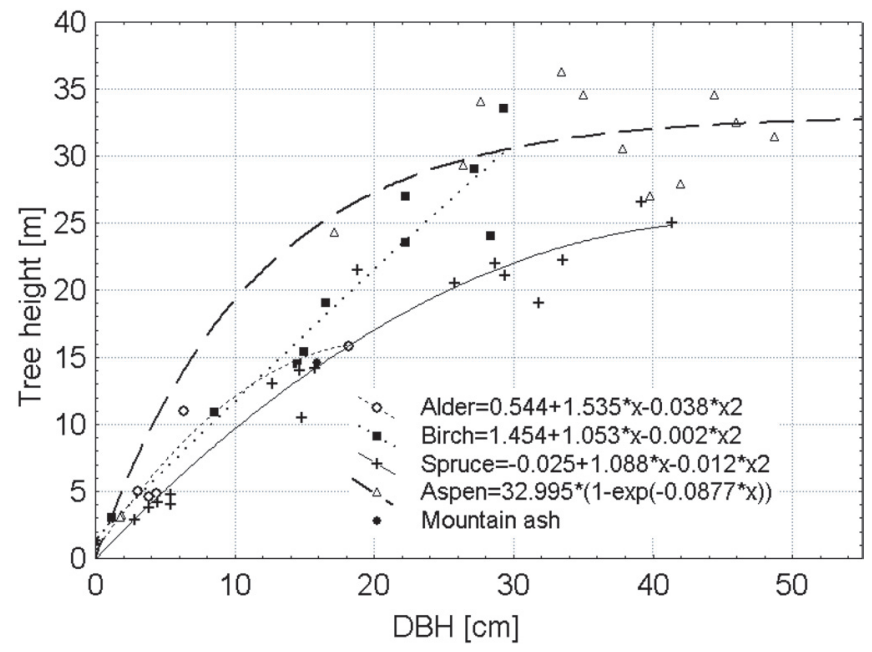

Figure 3. Allometric relations between tree $\mathrm{DBH}$ and height (obtained by measurement in wind-fallen trees). 


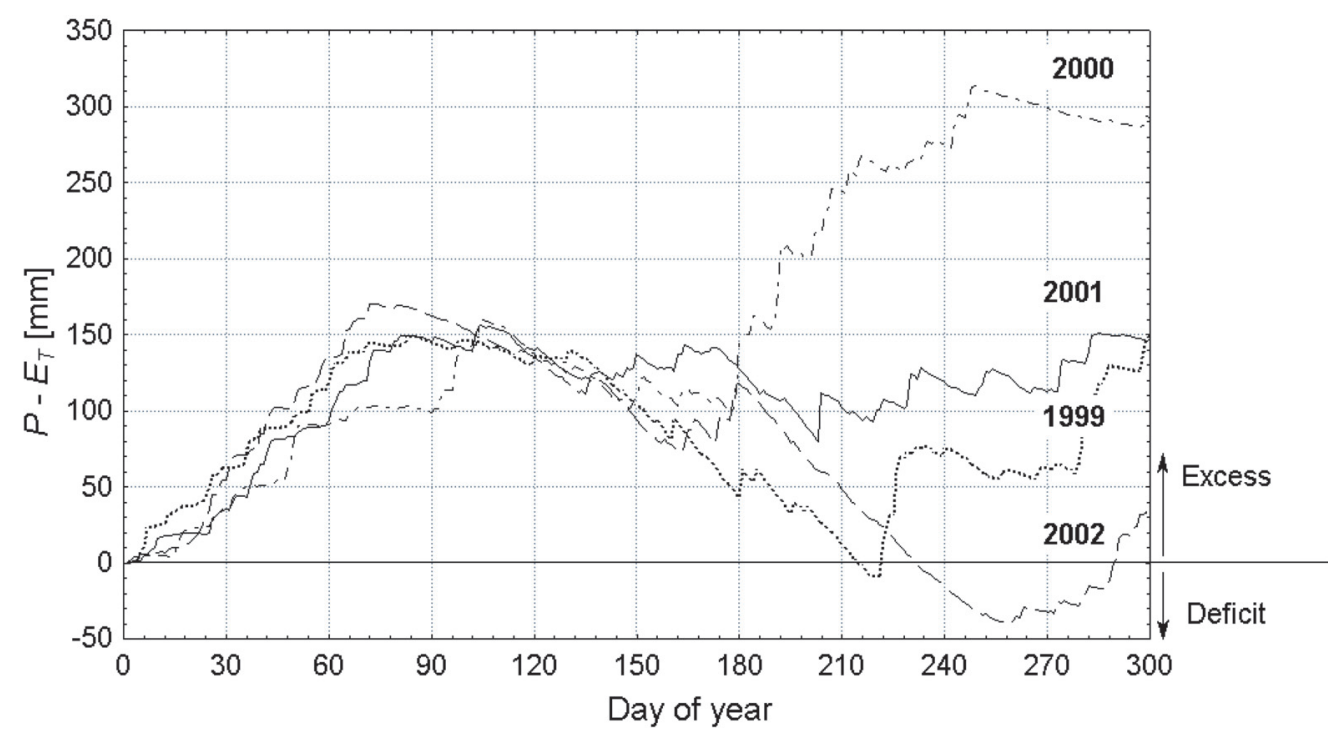

Figure 4. Changes of rainfall deficit during the growing seasons of 1999 to 2002 (data from Central Forest Biosphere Nature Reserve).
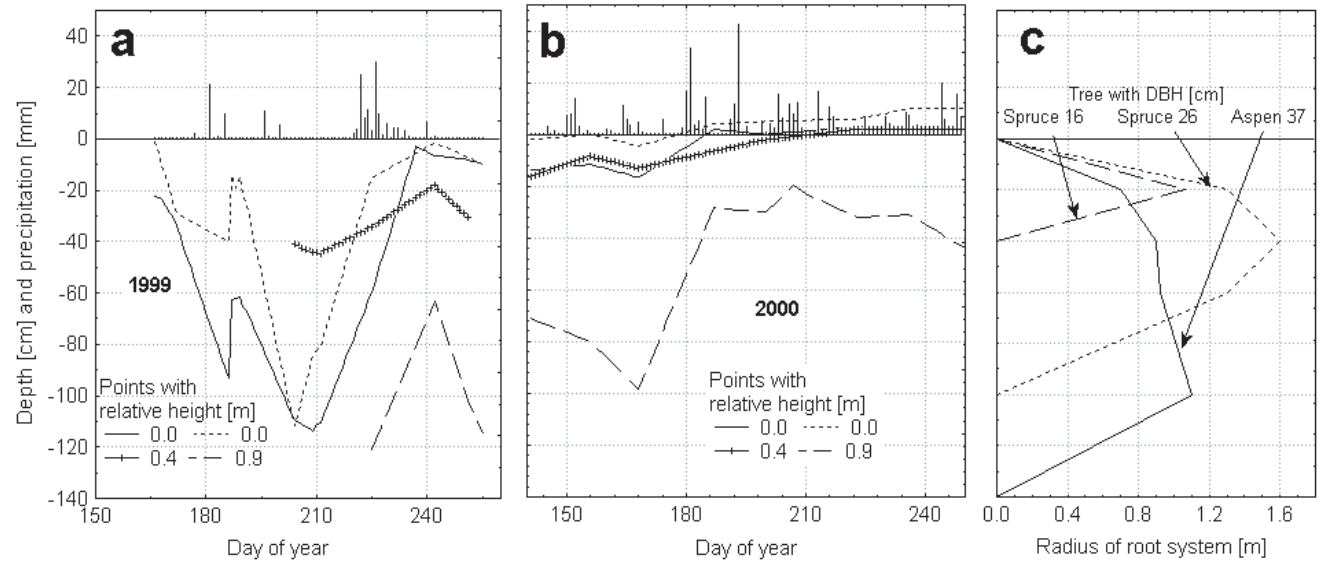

Figure 5. Seasonal dynamics of underground water table (lines) and precipitation (bars, data from Central Forest Nature Reserve) for two contrasting years of 1999 (a) and 2000 (b) with the schematic drawing of vertical cross-section of enveloping surfaces of tree rooted zones (taken as rotation bodies) (c).

warm and dry (Fig. 4). In particular, drought stress in the second part of summer 1999 was expressed at the experimental plot by the considerable decreasing of stand transpiration obtained by means of sap flow measurements in August [14]. Precipitation lack influenced dramatically the underground water table (Fig. 5). The summer of 2002 was characterised by extreme drought in the entire Central Russia region [16]. The beginning of vegetation periods of 1999-2000 was characterised by several strong frosts (approximately until May 20-25). They resulted in significant reducing the foliage amount in aspens comparing with other years.

\subsection{Seasonal growth curves of individual trees in the wet year 2000}

In 2000 the radial stem growth of most selected sample trees of different species began in early May and continued until mid- dle of August (Fig. 6), what corresponds with the typical period from the start of foliage development until the start of foliage yellowishing in the region. However the smallest spruce trees and some deciduous trees (especially birches) started their growth later (in the second part of May or even in the middle of June). The aspen trees with DBH less than $34 \mathrm{~cm}$ did not grow in general during the whole season. As an exception, the growth of 2 sample trees (spruce with DBH $46 \mathrm{~cm}$ and aspen with $\mathrm{DBH} 46 \mathrm{~cm}$ ) was observed during the whole vegetation period until middle of October.

The seasonal patterns of stem radial growth rate (Fig. 7) showed that intensive growth of deciduous tree species was shifted to the second half of summer and reached maximum in middle of July. The stem growth of the spruce had maximum in early July and was significant since early May to the late August. The mean growth rate of the spruce trees was several (at least three) times higher comparing with birch and aspen 

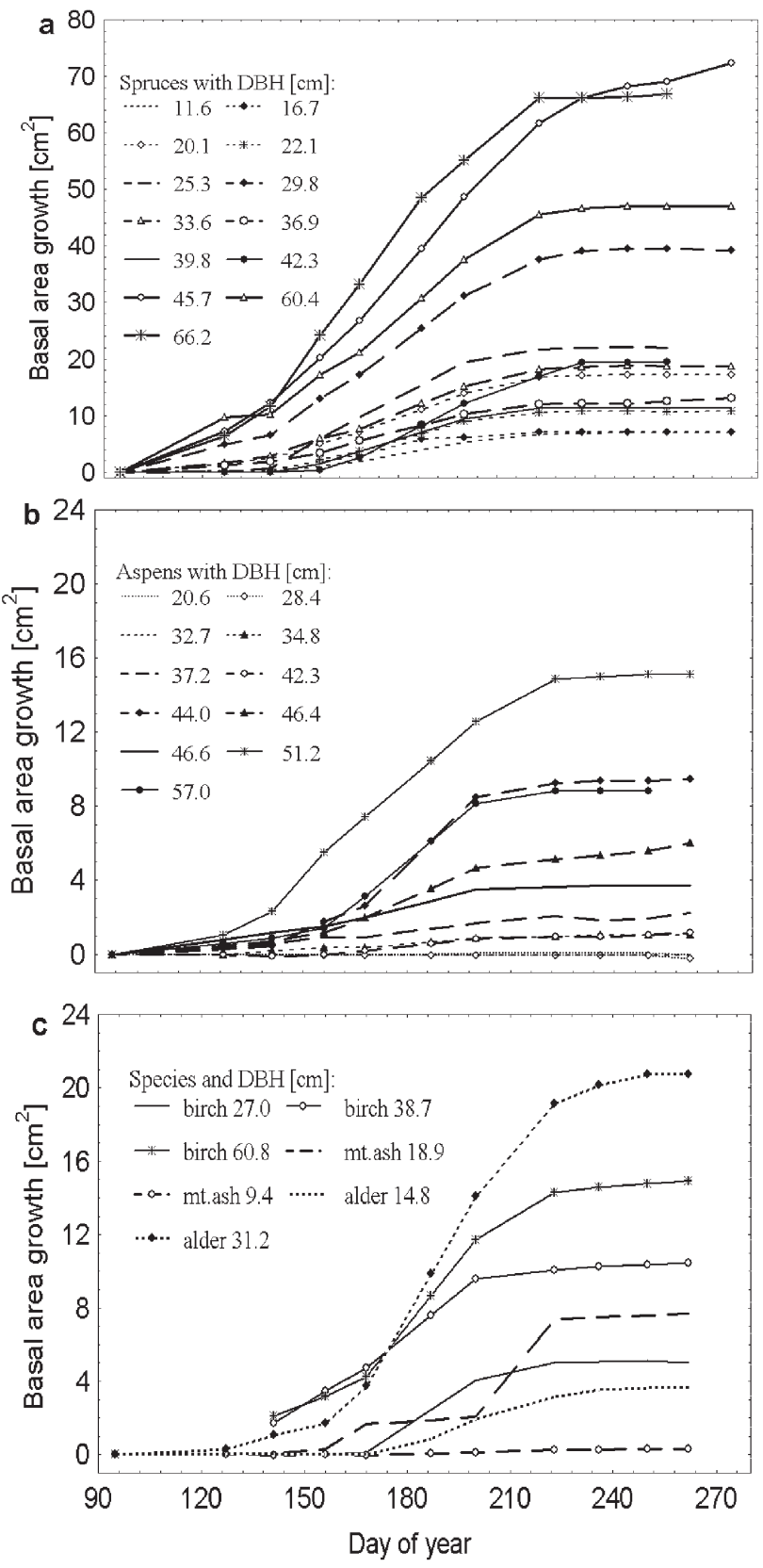

Figure 6. Growth of basal area in individual trees at the experimental stand in Peno during the growing season 2000.

during the whole vegetation season (Fig. 7), whereas the mean diameter of sample spruces was smaller than mean diameters of aspens and birches. Mean spruce growth was also higher than the growth of the alder in understorey layer, but only during the first part of summer. "Strange" growth behaviour of mountain ash was possibly evoked by insufficient number of sample trees.

\subsection{Stand seasonal growth pattern in 2000}

Seasonal increment of basal area in spruce represented over $80 \%$ of the entire stand basal area increment (as indicated by

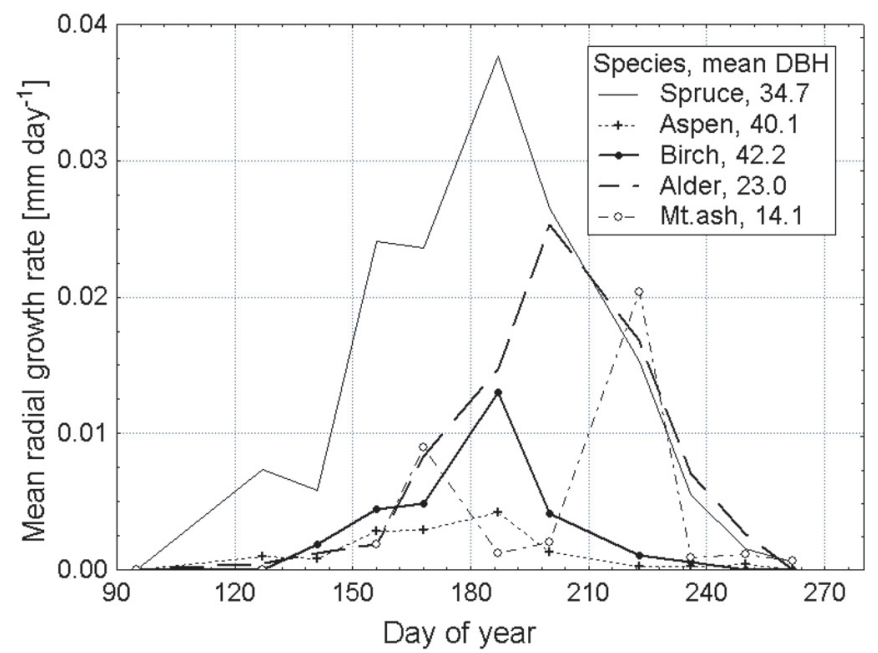

Figure 7. Mean growth rate of stem radius in different tree species at the sample plot in 2000 .

scaling the data up to the stand level). Increment in aspen and alder, each represented over $5 \%$ of the stand total seasonal increment, while the total basal area of aspen was 10 times higher compared to alder. Thus, the stand basal area dynamics showed the transformation of secondary stand with domination of aspens into the stand with dominant spruce and significant admixture of alder in wet part of the experimental plot.

\subsection{Comparison of seasonal increment in stem radius measured by dendrometers and obtained from analysis of tree rings}

Comparison of seasonal tree radial growth measured by dendrometers and obtained from analysis of tree rings showed significantly better correlation between two methods for aspen when for spruce ( $r^{2}$ for spruce was 0.28 and 0.54 for 2000 and 2001 , respectively and 0.17 and 0.16 for these years for aspen). In particular, zero or very small growth rates were recorded in four aspens with DBH 20.6, 28.4, 32.7 and $42.3 \mathrm{~cm}$ at measurements made by dendrometers in 2000 , whereas at analysis of tree rings their growth rate reached values between 0.5 and $0.7 \mathrm{~mm}$ in the same year. One of the reasons of such differences is a possible methodological error: if the actual tree growth is close to zero, the corresponding annual ring is practically invisible on the cores and consequently a ring from 1999 could be erroneously identified as 2000. Another possible reason of this contradiction could be a bark pressing by dendrometers, which could evoke the underestimation of real growth by dendrometers. The cross-dating showed, that relating the annual ring widths of these aspen trees in 2000 to 1999 and taking the corresponding data of dendrometers as ring width for 2000 increased the mean correlation of their ring widths with ring widths of other trees from 0.11 to 0.37 . That is why the first explanation (i.e. really zero or very small width of ring in 2000) was considered. The exclusion of suspicious data from the analysis considerably improved the correlation between stem radial growth estimated by dendrometers and from core analysis: 

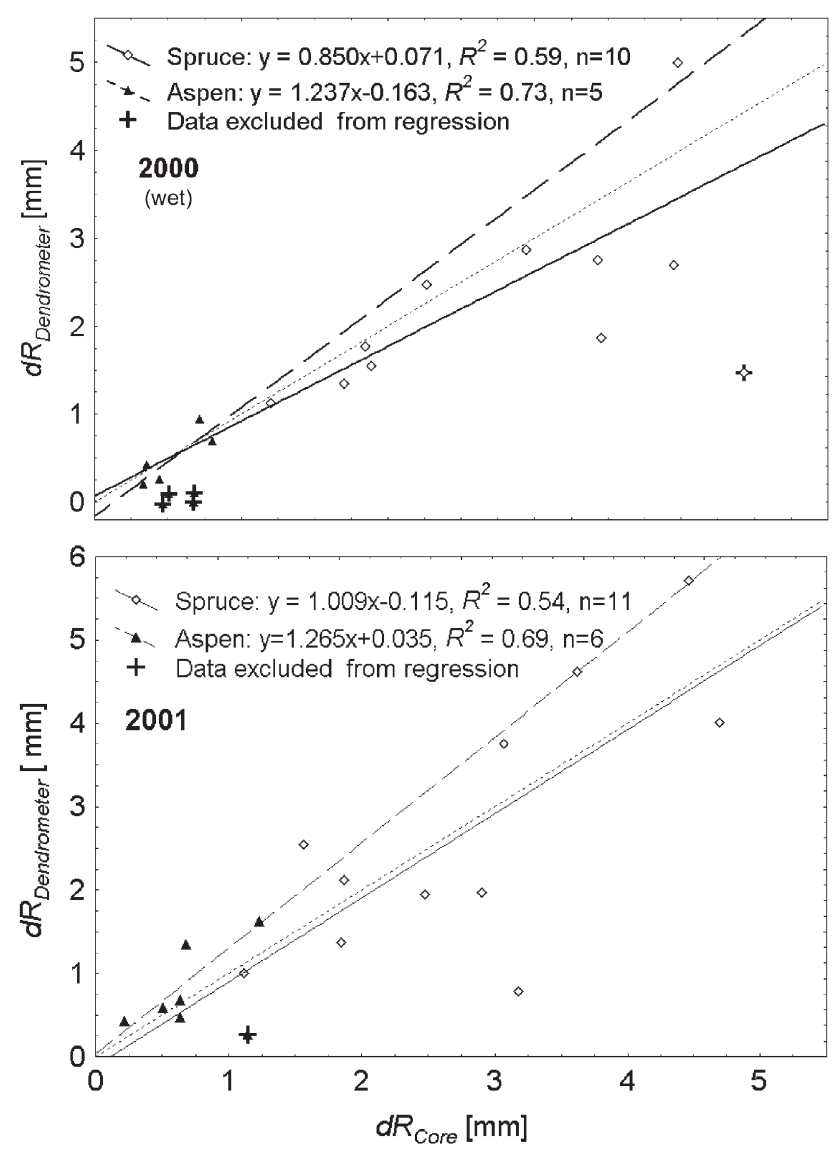

Figure 8. Comparison of annual radial increment as measured by dendrometers and by evaluating of cores. Linear regression was calculated for spruce and aspen trees together.

$r^{2}$ for spruce was 0.59 and 0.54 for 2000 and 2001, respectively and 0.73 and 0.69 for these years for aspen (Fig. 8).

\subsection{Annual stem growth of different species in 1999-2002}

The aspen trees showed significantly lower growth of basal area in absolute and relative terms when compared to spruce during all period of measurements. This difference was observed at both dendrometric and tree ring measurements. This trend was more pronounced in 2000 , when the relative growth of spruce basal area $\left(\boldsymbol{d} \boldsymbol{S}_{\boldsymbol{r}}\right)$ was from 1.5 to $12 \%$, whereas the relative growth of aspen was from 0.0 to $0.5 \%$, only (Fig. 9).

Aspen showed the lowest $\boldsymbol{d} \boldsymbol{S}_{\boldsymbol{r}}$ during the wet season of 2000 and the highest growth for the driest season of 2002 (Fig. 9). The growth of spruce was more stable from year to year compared to aspen (mean inter-annual variance of $\boldsymbol{d} \boldsymbol{S}_{\boldsymbol{r}}$ was $30 \%$ for spruce and $58 \%$ for aspen) and it was relatively independent on moisture conditions. The reasons of low spruce growth in 1999 are unclear. Probably it can be explained by influence of anomalous environmental conditions during the summer of 1998 characterised by extremely high over-watering: the total
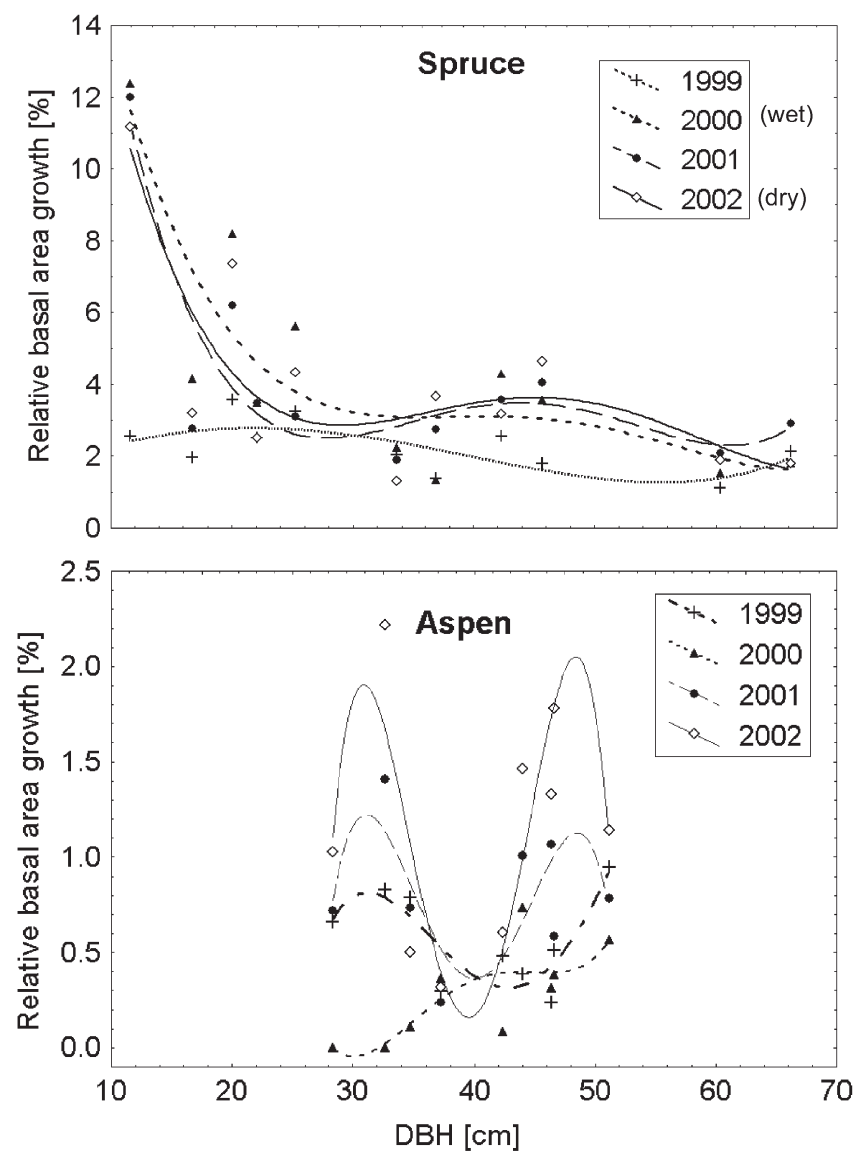

Figure 9. Relative seasonal growth of basal area in spruce and aspen in 1999-2002 as measured by microscopic evaluation of cores (approximation by polynomials of fourth order). Applied parameterisations: for spruce -1999 : $y=7 \cdot 10^{-7} x^{4}-2 \mathrm{E}-05 \mathrm{x}^{3}-0.0036 \mathrm{x}^{2}+$ $0.1617 \mathrm{x}+1.0623,2000: \mathrm{y}=7 \cdot 10^{-6} \mathrm{x}^{4}-0.0014 \mathrm{x}^{3}+0.0957 \mathrm{x}^{2}-$ $2.8271 \mathrm{x}+33.663,2001: \mathrm{y}=1 \cdot 10^{-5} \mathrm{x}^{4}-0.0025 \mathrm{x}^{3}+0.1567 \mathrm{x}^{2}-$ 4.1748x + 42.294, 2002: $\mathrm{y}=9 \cdot 10^{-6} \mathrm{x}^{4}-0.0017 \mathrm{x}^{3}+0.1138 \mathrm{x}^{2}-$ $3.1968 \mathrm{x}+34.877$; for aspen -1999 : $\mathrm{y}=-2 \cdot 10^{-5} \mathrm{x}^{4}+0.0035 \mathrm{x}^{3}-$ $0.2285 \mathrm{x}^{2}+6.3888 \mathrm{x}-64.024,2000: \mathrm{y}=3 \cdot 10^{-5} \mathrm{x}^{4}-0.0045 \mathrm{x}^{3}+$ $0.2676 \mathrm{x}^{2}-6.8663 \mathrm{x}+64.692,2001: \mathrm{y}=-0.0001 \mathrm{x}^{4}+0.0228 \mathrm{x}^{3}-$ $1.3399 x^{2}+34.466 x-325.92,2002: y=-0.0003 x^{4}+0.0492 x^{3}-$ $2.8735 x^{2}+73.383 x-689.54$

precipitation for growing season (from May to September) was $210 \mathrm{~mm}(56 \%)$ higher, than long-term means. Higher annual growth (measured by dendrometers) also occurred in other considered deciduous species, birch and mountain ash, during relatively dry season 2001 compared to wet 2000. For example, basal area growth of birch sample trees was 2-3 times higher in 2001 than in 2000.

In spruce $d S_{r}$ decreased with DBH over all years under consideration. In contrast in aspen $\boldsymbol{d} \boldsymbol{S}_{\boldsymbol{r}}$ increased with $\mathrm{DBH}$ in the wet season 2000, whereas in other seasons the dependence of $\boldsymbol{d} \boldsymbol{S}_{\boldsymbol{r}}$ on DBH had two peaks. No significant trend was observed in aspen for other seasons. Basal area growth of the birch trees decreased with increasing DBH (data from dendrometers for 2000 and 2001). 


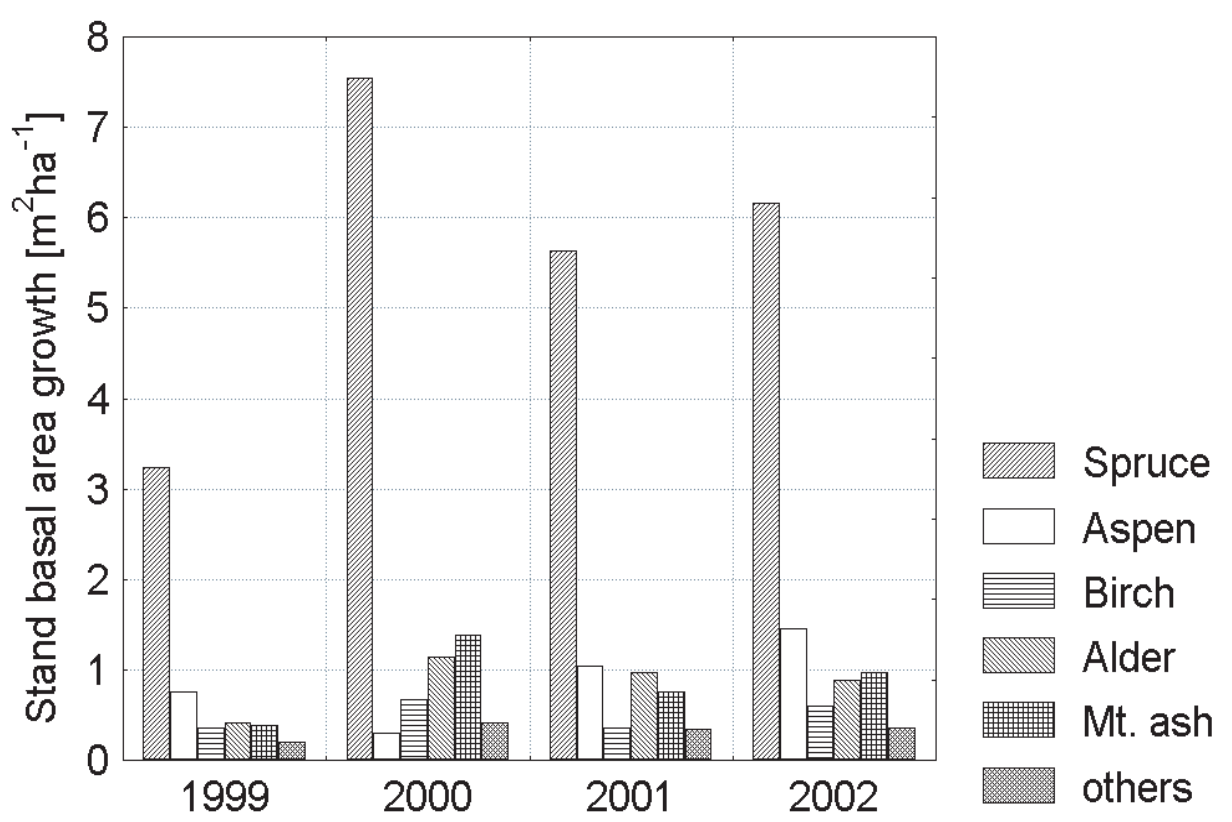

Figure 10. Growth of stand basal area in 1999-2002 as measured by microscopic evaluation of cores.

\subsection{Stand seasonal growth in 1999-2002}

Spruce absolutely dominated in the stand basal area growth for all years under consideration (Fig. 10). This domination was especially pronounced for wet season 2000 , when the spruce growth reached maximum and aspen growth felled to minimum over the seasons 1999-2002. The total stand basal area growth ranged from $5.3 \mathrm{~m}^{2} \mathrm{ha}^{-1}$ in 1999 to $11.4 \mathrm{in} \mathrm{m}^{2} \mathrm{ha}^{-1}$ in 2000 .

\section{DISCUSSION}

Aspen is a pioneer tree species with high initial growth rate and relatively short lifetime. In contrast, spruce is a dominant species of primary forests in the region with slower growth and longer life. That is why higher growth of aspen compared to spruce in mixed spruce-aspen stands could be expected [7]. In our case the seasonal radial growth for spruce was several times higher than for aspen during all periods of measurements. Nevertheless this difference was more pronounced in "wet" growing season of 2000 when compared with "dry" 1999 and 2001-2002. The possible reasons of relatively low (compared to spruce) growth of aspen are:

- Natural decreasing in growth rate of aspen with age ([23], Fig. 11) and massive damage of aspen wood by pest and fungi attacks.

- Over-watering especially of deeper soil layers resulted in higher hypoxia in aspen with its deeper root system when compared to spruce with its shallow root systems $[5,19]$.

- The frosts in the second part of May in 1999-2000 damaged many young leaves of aspens at experimental plot and, therefore, reduced potential carbon assimilation capacity of aspens in these years.

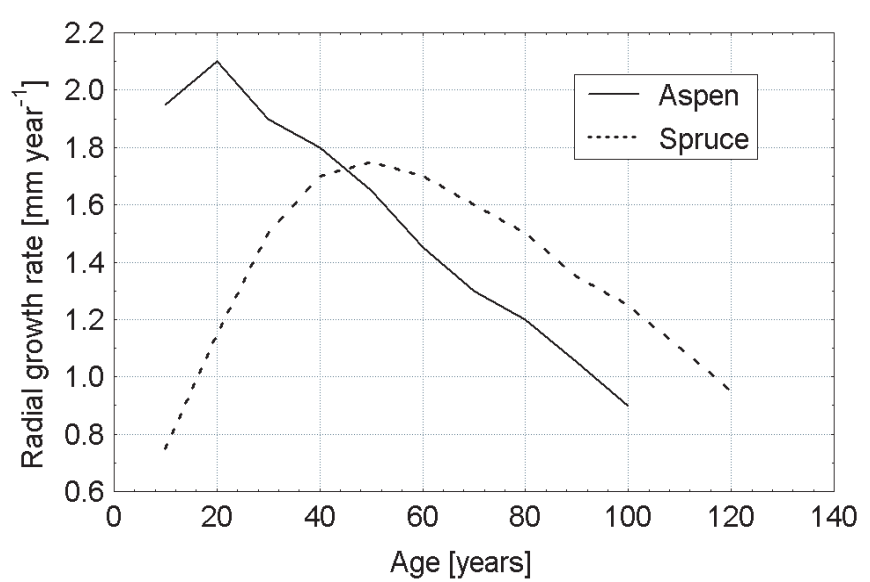

Figure 11. Growth rate of spruce and aspen according to yield tables (Zagreev, 1992).

The decreasing dependence of relative growth of basal area $\left(\boldsymbol{d} \boldsymbol{S}_{\boldsymbol{r}}\right)$ on DBH for spruce trees for all considered growing seasons indicates that the growth conditions for all diameter classes of spruce trees can be classified as optimal. In particular, this dependence is typical for natural spruce regeneration, too. The increasing dependence of $\boldsymbol{d} \boldsymbol{S}_{\boldsymbol{r}}$ on DBH (i.e. small growth of small trees) in aspen for growing season of 2000 (wet weather conditions) corresponded to the observed diameter distribution (see Fig. 1) with aspen regeneration missing. Moreover the existing small aspen trees were dying rapidly (including our smallest sample tree with $\mathrm{DBH}=20.6 \mathrm{~cm}$, which died during the season 2002). Growth of aspen was significantly higher during dry seasons, and not dependent on DBH, i.e., drought was rather favourable for aspen. Beside of the soil water regime 
(a)

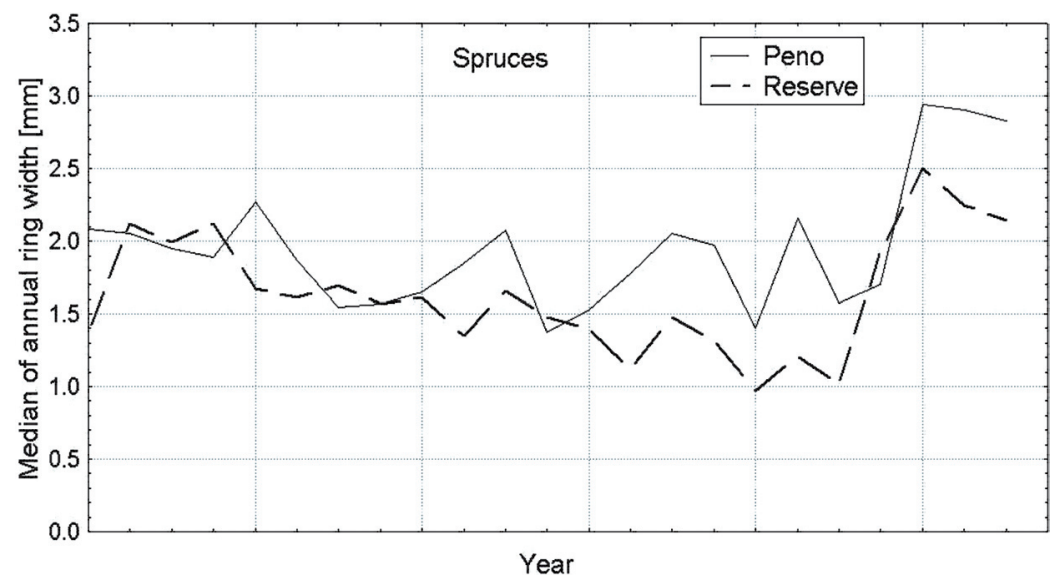

(b)

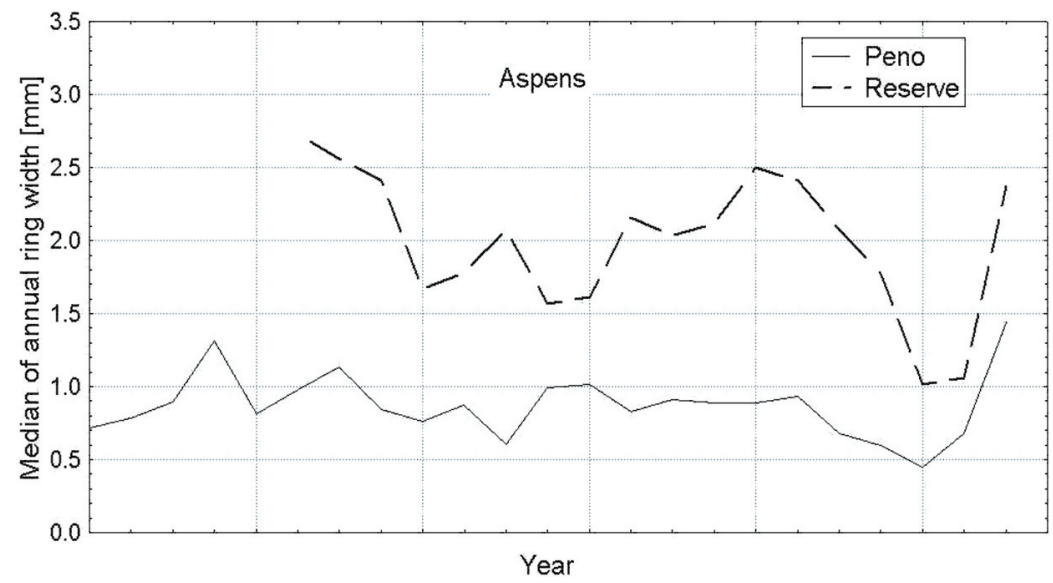

(c)

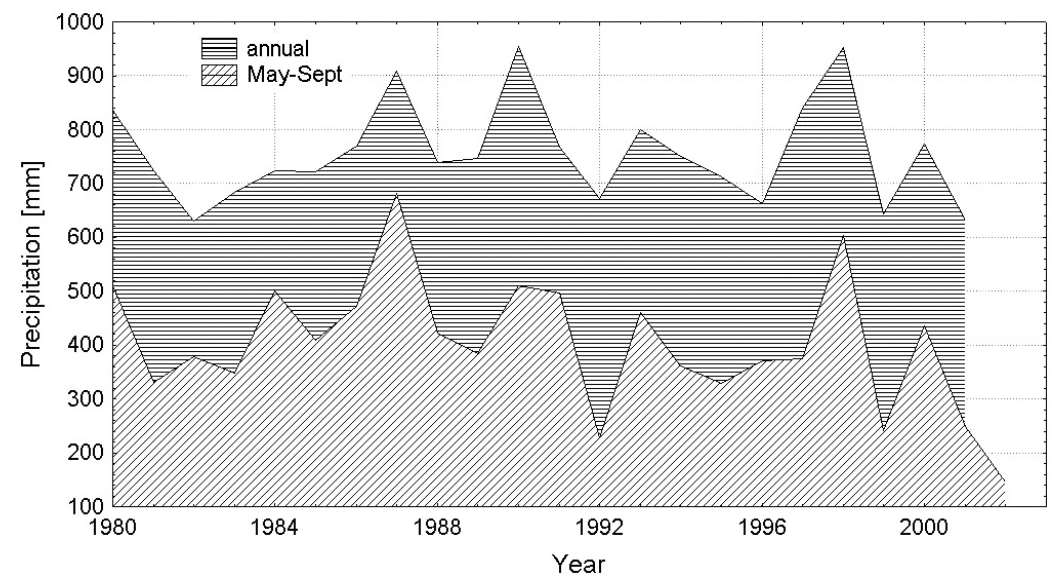

Figure 12. Medians of annual ring width of spruces (a) and aspens (b) in Peno and in Central Forest Biosphere Natural Reserve; seasonal and annual precipitation totals (Reserve) (c).

the within-species competition for light seems to be the main factor limiting growth of aspens (see, for example, [18]), occurring mostly in compact bio-groups, consisting of trees of similar height (see Fig. 3). Shading of aspens by spruces which were mostly of lower height was not significant (see Figs. 1 and 3). A single solitary growing relatively small $(\mathrm{DBH}=32.7 \mathrm{~cm})$ sample tree in the wet part of plot showed the highest radial growth and $\boldsymbol{d} \boldsymbol{S}_{\boldsymbol{r}}$ comparing with other sample aspens (Fig. 9).
The comparison of above discussed dendrochronological measurements with similar measurements carried out in the same time in the forest with similar species composition (on the soil with similar texture, but drier than in Peno experimental site) in CFBR [1] showed that although the growth of spruces was slightly higher at Peno site (but this difference is not significant by $t$-test with $95 \%$ confidence level), the aspen growth is significantly higher at CFBR site (Fig. 12). Consequently, if 
at Peno site the annual radial increment of spruces was always in 1.5 to 6 times higher than in aspens, at experimental site in CFBR, in contrast, the aspen radial increment was higher, than for spruce for all years since 1985, except 1999-2001. Aspen growth reached minimum at both sites in 2000, when high water table was combined with foliage damage by late spring frost and it reached the local maximum in the extremely dry growing season of 2002. Spruce growth reached maximum at both sites in 2000 and decreased slightly only in 2001-2002, whereas severe drought stress occurring in the CFBR at the same time manifested in the mass decline of spruces (D. Kozlov and F. Tatarinov, unpublished). Although many spruces were fallen, the growth of survived trees did not reduce significantly compared to previous year. In the over-wetted site Peno no spruce decline was observed, but significant windfall of living aspen trees (usually associated with breaking of stems evidently damaged by fungi), was observed in 2001-2002.

\section{CONCLUSIONS}

1. Natural succession of spruce, which was gradually replacing aspen, was observed at the experimental plot. Nevertheless, repeated dry summers, give a certain advantage to aspen (better soil water conditions) compared to spruce growth (see also [14]).

2. Higher inter-annual and space variability of growth rates during all period of observations was observed in spruce compared to aspen. In particular, growth rates of spruce and aspen were comparable under drier moisture conditions, on the other hand spruce growth rate in the wet site was several times higher than in aspen.

3. In 2002 during the drought stress the high growth of aspens was observed both at dry and at wet sample plots. Although this drought resulted in decline (fall) and death of spruce trees in many regions of Central Russia (including CFBR, but not in Peno sample plot), it did not affect the growth rates of survived spruce trees.

Acknowledgments: These studies were founded by the European Commission within the framework of the INCO-COPERNICUS research program (Grant IC15-CT98-0120).

\section{REFERENCES}

[1] Vygodskaya N., Tatarinov F., Kurbatova J., Kozlov D., Bochkarev Y., Puzachenko M., Varlagin A., Abrazko M., Schultze E.-D., Effects of extreme soil moisture events on mortality and annual growth of spruce trees in South-European taiga, 12th International Boreal Research Association Conference 3-7 May 2004, Fairbanks, Alaska, Book of abstracts, 2004, p. 200.

[2] Cermak J., Kucera J., Transpiration of fully grown trees and stands of spruce (Picea abies (L.) Karst.) estimated by the tree-trunk heat balance method, in: Swanson R.H., Bernier P.Y., Woodward P.D. (Eds.), Proc. Forest Hydrology and Watershed Measurements, Vancouver, Canada Aug. 1987, Publ. No. 167, IAHS-AISH, Wallingford, UK, 1987, pp. 311-317.

[3] Cermak J., Kucera J., Scaling up transpiration data between trees, stands and watersheds, Silva Carelica 15 (1990) 101-120.

[4] Cermak J., Michalek J., Selection of sample trees in forest stands using the "quantils of total" (in Czech), Lesnictvi (Forestry) 37 (1991) 49-60.
[5] Cermak J., Kucera J., Water uptake in healthy and ill trees, under drought and hypoxia and non-invasive assessment of the effective size of root systems, in: Persson H. (Ed.), Above and below-ground interactions in forest trees in acidified soils, Uppsala, Sweden, 1990, pp. 185-195.

[6] Cermak J., Kucera J., Prax A., Tatarinov F., Nadyezhdin V., Longterm course of transpiration in a floodplain forest in southern Moravia associated with changes of underground water table, Ekologia (Bratislava), 20 Suppl. 1 (2001) 92-115.

[7] Kabzems R., Garcia O., Structure and dynamics of trembling aspen - white spruce mixed stands near Fort Nelson, B.C., Can. J. For. Res. 34 (2004) 384-395.

[8] Karpov V.G., Shaposhnikov E.S., Spruce forests of the territory, in: Regulation factors of ecosystems of spruce forests, Nauka publishers, Moscow, 1983, pp. 7-34 (in Russian).

[9] Lebourgeois F., Cousseau G., Ducos Y., Climate-tree-growth relationships of Quercus petraea Mill. Stand in the Forest of Bercé (Futaie des Clos, Sarthe, France), Ann. For. Sci. 61 (2004) 361-372.

[10] Matheron G., Principles of geostatistics, Econ. Geol. 58 (1963) 1246-1266.

[11] Minayeva T.Y., Shaposhnikov E.S., Mass drying out of spruce stands, in: Smirnova O.V., Shaposhnikov E.S. (Eds.), Forest successions in protected areas of Russia and problems of biodiversity conservation, St-Petersburg, Russian Botanical Society, 1999, pp. 354-360 (in Russian).

[12] Oltchev A., Constantin J., Gravenhorst G., Ibrom A., Heinmann J., Schmidt J., Falk M., Morgenstern K., Richter I., Vygodskaya N., Application of six-layer SVAT model for simulation of evapotranspiration and water uptake in a spruce forest, J. Phys. Chem. Earth 21 (1996) 195-199.

[13] Oltchev A., Cermak J., Gurtz J., Kiely G., Nadezhdina N., Tishenko A., Zappa M., Lebedeva N., Vitvar T., Albertson J.D., Tatarinov F., Tishenko D., Nadezhdin V., Kozlov B., Ibrom A., Vygodskaya N., Gravenhorst G., The response of the water fluxes of the boreal forest region at the Volga's source area to climatic and land-use changes, J. Phys. Chem. Earth 27 (2002) 675-690.

[14] Oltchev A., Cermak J., Nadezhdina N., Tatarinov F., Tishenko A., Ibrom A., Gravenhorst G., Transpiration of a mixed forest stand: field measurement and simulations using SVAT models, Boreal Environ. Res. 7 (2002) 389-398.

[15] Oltchev A., Concept of an evaporation model for non-uniform forest landscapes, J. Rus. For. Soc., 2003, pp. 55-64 (in Russian).

[16] Russian Hydrometeorological Center, Analysis of climate of Northern hemisphere in 2002, Informational bulletin, 2003, http:// hmc.hydromet.ru/ (in Russian).

[17] Sukachev V.N., Manual of investigation of forest types, Gosizdat, Moscow, 1931 (in Russian).

[18] Tkachenko M.E., General forestry, Goslesbumizdat, Leningrad, 1952 (in Russian).

[19] Tripepi R.R., Mitchell C.A., Metabolic response of River birch and European birch roots to hypoxia, Plant Physiol. 76 (1984) 31-35.

[20] Vygodskaya N., Milukova I., Tatarinov F., Varlagin A., et al., Adaptation peculiarities of Picea abies to changes of hydrometeorological factors, Mat. 1st GCTE Science Conf., Woods Hole, USA, 1994, p. 90.

[21] Vygodskaya N., Puzachenko Yu., Kozharinov A., Zavelsakaya N., Tchernychev M., Tatarinov F., Varlagin A., Milukova I., Longterm effects of climate on Picea abies communities in the South European Taiga, J. Biogeogr. 22 (1995) 2851-2862.

[22] Vygodskaya N.N., Schultze E.-D., Tchebakova N.M., Karpachevskii L.O., Kozlov D., Sidorov K.N., Panfyorov M.I., Abrazko M.I., Shaposhnikov E.S., Solnzeva O.N., Minaeva T.Y., Jeltuchin A.S., Wirth C., Pugachevskii A.V., Climatic control of stand thinning in unmanaged forests of the southern taiga in European Russia, Tellus 54B (2002) 443-461.

[23] Zagreev (Ed.), Forest Inventory Handbook, all union rules and regulations for the forest inventory, Kolos, Moscow, 1992, pp. 298-321 (in Russian). 